\title{
Fast-Food Çalışanlarının İş Sorunlarının İş ve Yaşam Tatminlerine Etkisi: Mersin Şehir Merkezinde Bir Araştırma
}

\author{
The Impact of Fast Food Employees' Work Related Problems on Job and Life \\ Satisfaction: A Research in City Center of Mersin
}

\author{
Yrd. Doç. Dr. Dilek Atçı - Prof. Dr. A. Celil Çakıcı - Arş. Grv. Çağdaş Ertaş
}

\begin{abstract}
Öz
Çalışanların işlerinde yaşadıkları sorunlar iş tatminleri ve hatta yaşam tatminleri üzerinde etkili olmakta, bu da verdikleri hizmetin kalitesini etkilemektedir. Bu çalışmanın amacı Mersin şehir merkezinde faaliyet gösteren fast-food işletmelerinde çalışanların sorunlarını ve bu sorunların çalışanların iş ve yaşam tatminlerine etkilerini tespit etmektir. Veri toplama amactyla geliștirilen anket, kolayda örnekleme yöntemiyle, 15 Mayıs-15 Ağustos 2011 tarihleri arasında Mersin şehrindeki yirmidört fast-food işletmesinin çalışanlarına uygulanmıştır. 174 çalışanın katıldığı araştırma sonucunda fast-food çalışanlarinin sorunlarınin yönetsel, çalışanlar arası ve çalışma koşulları konularında gruplanabileceği ortaya çıkmıştır. Çalışma koşullarında sorun yaşama bakımından kadınlar erkeklere, 18-29 yaș arasinda olanlar 30-55 yaş grubuna ve bekârlar evlilere kıyasla daha sık sorun yaşamaktadırlar. Çalışanlar arası sorunlar, iş tatminini olumsuz yönde etkilerken, çalışma koşulları ile yönetsel sorunlar yaşam tatminini olumsuz yönde etkilemektedir.
\end{abstract}

Anahtar Kelimeler: Fast-food İşletmeleri, Çalışan Sorunları, Ișs Tatmini, Yaşam Tatmini, Mersin

\begin{abstract}
Work related problems of employees have influence over job satisfaction, even life satisfaction leading poor service quality. This study aims to identify challenges that employees face and the effect of these challenges on
\end{abstract}

their job and life satisfaction in the fast-food businesses operating in the city center of Mersin. A questionnaire developed to collect data, was applied to employees of twenty four fast-food establishments in Mersin between 15 May and 15 August 2011 through drop-ball technique via convenience sampling. Totally, 174 completed questionnaires were received. As a result, problems of fast-food industry employees' can be grouped as "managerial,", "inter-workers" and "working conditions". When working conditions taken into consideration, it has been revealed that women, employee in 18-29 years old and singles have experienced more frequent problems in contrast with men, employee in 30-55 years old and married people, respectively. Besides, just as interworkers problems negatively affect the job satisfaction, problems related with the working conditions and managerial negatively impact the life satisfaction.

Keywords: Fast-food Companies, Employee İssues, Job Satisfaction, Life Satisfaction, Mersin

\section{Giriş}

Dünya genelinde yapılan seyahatler, iletişim, medya ve farklı kültürler yeryüzündeki pazarları kaynaştırmış, küresel bir pazar oluşturmuş ve dünya genelinde ortak bir kültür oluşmasına zemin hazırlamıştır. Fast-food sektörü de oluşan bu ortak kültürlerden birisidir (Park, 2004, s. 87-88). Fast-food düşük fiyatlı, hızlı sunulan, elde yenebilen ve fazla dayanıklı

Yrd. Doç. Dr. Dilek Atçı, Mersin Üniversitesi Turizm Fakültesi, dilek-tetik@hotmail.com

Prof. Dr. A. Celil Çakıcı, Mersin Üniversitesi Turizm Fakültesi, celilc@yahoo.com

Arş. Grv. Çağdaş Ertaş, Şırnak Üniversitesi Turizm ve Otel İşletmeciliği Yüksekokulu, ertascagdas@hotmail.com 
olmayan yiyecek türleri olarak tanımlanabilir. Ancak, düşük fiyatlı olmasına rağmen bu, müşterilerin fastfood ürününden ve sunumdan kalite beklentilerini azaltmamaktadır (Lam ve Zhang, 2003, s.214). Sik1 rekabet şartlarının hüküm sürdüğü fast-food sektöründe rekabet üstünlüğü elde etmek için müşteri memnuniyetini sağlamak büyük önem taşımaktadır. Bunun için ise ürünlerin ve ortamın (donanım) yanı sıra, sunulan hizmet (yazılım) büyük rol oynamaktadır (Lam ve Zhang, 2003, s.214). Çünkü esas anlamda farklılığı yaratacak olan, hizmetin sunumu, dolayısıyla onu sunan çalışanlar olmaktadır. Çalışanların iş ortamındaki sorunları, öncelikle çalışanların iş ve yaşam tatminini, sunulan hizmetin standardını ve sonucunda müşteri memnuniyetini etkileyebileceğinden, bu sorunların ve etkilerinin belirlenmesi büyük önem arz etmektedir (Pienaar ve Willemse, 2008, s.1054).

Müşteri memnuniyetini sağlamada kilit rol oynayan çalışanların işlerinden memnun olmaları, ancak onlara iyi bir çalışma ortamı sağlanarak gerçekleştirilebilir. Bu açıdan, fast-food sektöründe çalışanların sorunları ve bu sorunların iş ve yaşam tatminleriyle ilişkisi dikkate alınması gereken önemli bir konu olarak görülmektedir.

Çalışmanın uygulama alanı olan fast-food işletmeleri sınırlı ve standart menülere sahip işletmelerdir. $\mathrm{Bu}$ işletmeler klasik Taylorist tarzda kitle üretimi yapmaktadır, yoğun işbölümü ve uzmanlaşma vardır, işler rutin ve standarttır. Üretim sürecinin adımları ve süresi ayrıntılı olarak belirlenmiştir (Allan, Bamber ve Timo, 2006, s.404). İşlerin rutinliği dolayısıyla çalışanın karar verme ve yaratıcılığını kullanma şansı kalmamaktadır. Ayrıca sektördeki işlerin düşük statüsü ve düşük ücret, ilerleme şansı tanımaması dolayısıyla daha çok giriş seviyesi işler olarak düşünülmektedir ve tüm bu özellikleri dolayısıyla iş bırakmanın da yüksek olduğu bir sektördür (Allan, Bamber ve Timo, 2006, s.403). İşletmeler de yüksek iş bırakma dolayısıyla personel seçimi, eğitimi ve bağlilık arttırıcı uygulamalara itibar etmemekte, nasılsa kısa süre sonra kaybedeceği personeli için harcama yapmaktan kaçınmaktadır. Bu durum zaten düşük ücretle uzun saatler boyunca çalışan işgörenlerin, müşterilere karşı kayıtsızlı̆̆ına ve dolayısıyla sunulan hizmetin kalitesinin düşmesine ve satışların azalmasına yol açmaktadır. Bu da, müşteri memnuniyetinin azalmasını ve iş tatminsizliğinin daha da artmasını tetiklemekte, sonuçta iş bırakma oranları yüksel- mektedir. Böylelikle iş tatminsizliğinden müșteri tatminsizliğine uzanan "başarısızlık döngüsü" kendi kendini beslemektedir (Schlesinger ve Heskett, 1991, s.17). Bu başarısızlık kısır döngüsünü kırmak için öncelikle işletmelerin onu beslemekten vazgeçmeleri gerekmektedir. Çalışanlarını önemseyen işletmelerin başarısızlık döngüsünü, başarı zincirine dönüştürmeleri mümkün olabilecektir. Çalışmanın temel amacı bu zemine oturmaktadır.

Diğer taraftan, dünya ölçeğinde hızla büyüyen genelde yiyecek-içecek özelde fast-food işletmelerini uygulama alanı, çalışanlarını ise örneklem olarak almış, iş tatmini (Dienhart ve Gregoire, 1993; Hançer, 2001; Hançer ve George, 2003; Yazıcıŏlu ve Sökmen, 2007; Gill vd., 2010; Sezgin ve Ünlüönen, 2011; İçigen ve Uzut, 2012; Çoban ve İrmiş, 2014), yaşam tatmini (Ghiselli, Lopa ve Bai, 2001; Hayes ve Weathington, 2007), motivasyon (Dermody, Young ve Taylor, 2004; Curtis, Upchurch ve Severt, 2009) ve iş stresi (Chiang, Birtch ve Kwan, 2010) ile ilgili sınırlı sayıda araştırma olmakla beraber, fast-food çalışanlarının sorunlarını ve bu sorunların iş ve yaşam tatminlerine etkisini araştıran bir çalışmaya rastlanmamıştır. Belirtilen sebeplerle bu çalışmada Mersin'de şehir merkezinde faaliyet gösteren fast-food işletmelerinde çalışanların ne gibi sorunlar yaşadıkları, iş ve yaşam tatminleri ve yaşadıkları sorunların iş ve yaşam tatminlerine etkisi incelenmiştir. Çalışmada öncelikle çalışanların iş tatmini ve yaşam tatmini konusunun genelde hizmet, özelde fast food işletmeleri için taşıdığ 1 öneme odaklanan ilgili alanyazına değinilmekte, daha sonra ise bu konuda Mersin'de fast food işletmeleri üzerinde yapılan bir araştırmaya yer verilmektedir.

\section{Kuramsal Çerçeve}

Geçmişten günümüze işletmelerin odak noktaları değişime uğramıştır. Önceleri kendi içlerine odaklı olan işletmeler, değişen şartlarla birlikte var olma amaçlarını sorgulamak zorunda kalmış ve gözlerini dişarıya çevirmişlerdir. Günümüzde gelinen noktada ise tüketici memnuniyeti işletmelerin ayakta kalabilmesinin ön koşulu halini almıştır. Özellikle tüketiciyle etkileşimin yoğun olduğu hizmet işletmelerinde tüketici memnuniyeti, işletmelerin en önemsediği konulardan biridir.

Bilindiği üzere, hizmetin kendine özgü özellikleri gereği hizmet üretimi ve tüketimi eş zamanlıdır ve tüketici üretim sürecinin bir parçasıdır, başka bir deyişle 
üretim sürecinde bizzat yer alır (Zeithaml, Parasuraman ve Berry, 1985, s.33). Müşteriler, işletme hakkında izlenimlerini bu etkileşim anlarında (service encounter) belirler. Bu etkileşim anlarına gerçek anlar/ gerçeklik anları (moments of truth) denilmektedir ve bu anlarda müşteri işletmeyle ilgili bir yargıya varmaktadır. Ayrıca hizmetler, hizmeti sunandan ayrıştırılamaz. Hizmetin sunulduğu etkileşim anı sırasında çalışanın davranışları hizmetin kendisidir (Hartline ve Farrel, 1996, s.55). İște bu gerçeklik anlarında işletmenin fiziksel durumu, tüketiciye vaat ettikleri ne kadar mükemmel olursa olsun, hizmeti sunan kişilerin hizmet sunumundaki davranışları ve yaklaşımı, tüketicilerin kararını etkileyecektir. Üstelik hizmetlerin dayanıksız olması ve depolanamaması dolay1sıyla kötü hizmetten geri dönme şansı da yoktur. Bu açıdan çalışan memnuniyetinin de, tüketici memnuniyetinin ayrılmaz bir parçası olduğu düşünülebilir. Çünkü çalışanın işinden duyduğu tatmin/tatminsizlik eşzamanlı olarak tüketiciye yansıyabilmektedir.

Bu konuda temel alınan hizmet-kâr zinciri modeline göre, çalışan memnuniyeti, çalışan bağlılığı, müşteri memnuniyeti, müşteri bağlılı̆̆ı ve kârlılık arasında bağlantı vardır (Heskett vd., 1994, s.164). Özellikle, müşteri etkileşiminin fazla olduğu ve müşterinin üretim sürecine katılımının yoğun olduğu durumlarda -hizmet sektörü gibi- bu ilişkinin daha güçlü olduğu vurgulanmaktadır (Ram, Bhargavi ve Prabhakar, 2011, s.123). Modelde çalışanların iş tatminini ise, çalışma koşulları, işyerinin dizaynı, ödül ve takdir sistemleri gibi değiş̧enler etkilemektedir.

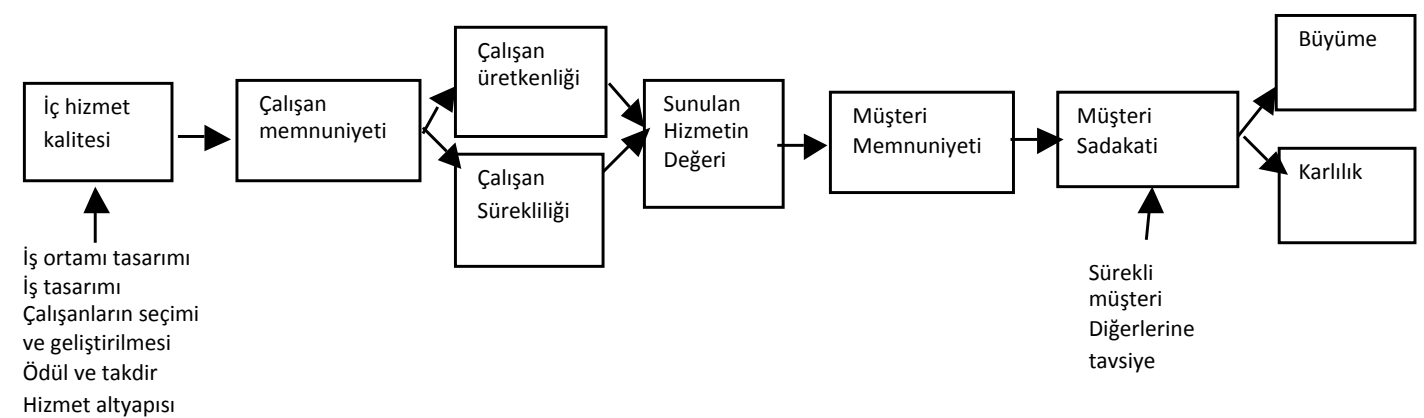

Kaynak: Heskett, J. L., Jones, T. O., Loveman, G. W., Sasser, W. E. ve Schlesinger, L. A. (1994). Putting the service-profit chain to work. Harvard Business Review 72 (2), s.166.

\section{Şekil.1. Hizmet-Kâr Zinciri Modeli}

Tatmin olan çalışanlar, müşteri tatminini de sağlayarak finansal başarıyla (kar ve büyüme) sonuçlanan bir zincir yaratırlar (Naseem, Sheikh ve Malik, 2011, s.41). Model, müşteri tatmini konusunda daha geniş bir bakış açısının gerekliliğini vurgulamaktadır.

Chi ve Gürsoy’un (2009) söz konusu modeli doğrular nitelikte sonuçlar elde ettikleri çalışmalarında, otel işletmelerinde çalışanların iş tatmininin finansal performans üzerinde doğrudan bir etkisinin olmadığını, ancak müşteri memnuniyeti aracıllğıyla dolaylı bir etkisinin olduğunu ortaya koymuşlardır. Çalışanların iş tatmini müşteri memnuniyetini ise doğrudan etkilemektedir. Bu durumda, çalışanlara iyi bir çalışma ortamının sunulması, bu zincirin ilk halkası olmaktadır. Bütün bunlar, özellikle hizmet sektöründe tüketici memnuniyeti sağlamada çalışanların mem- nuniyetinin önemini vurgulamaktadır. Çalışanların işlerinden duydukları memnuniyet, diğer bir deyişle iş tatmini ise özellikle iş kaynaklı birçok faktörden etkilenmektedir.

Burada dikkat çeken diğer bir unsur ise, çalışanların iş tatmini ve yaşam tatmini arasında da yine çokça tartışılan ilişkinin varlığıdır. Yaşam tatmini, kişinin genel olarak yaşamına ilişkin hissettikleri olarak tanımlanabilir. Genel yaşam memnuniyetinin belirleyici unsurları; bireyin iş yaşamı ve iş dışı yaşamındaki memnuniyetidir. Kişi zamanının büyük bir kısmını çalışarak geçirdiği için işi yaşamının önemli bir parçasıdır ve işinin özellikleri kişinin yaşamını etkiler (Uyguç v.d., 1998, s.193). Dolayısıyla, çalışanların iş tatmini iş ortamlarının dışındaki olay ve durumlardan etkilenirken, iş dışındaki olaylarla ilgili davranış 
ve duygular da iş tatmininden etkilenmektedir (Saari ve Judge, 2004, s.398). Bu yüzden yaşam tatmininin artmasında iş tatmini önemli bir faktör olarak görülebilir (Saldaml, 2008, s.702). Çünkü, bireyin iş yaşamındaki memnuniyeti, sadece iş yaşam alanı ile sınırlı kalmayıp özel yaşamına da taşabilmekte ya da bunun tersi de mümkün olabilmektedir (Bülbül ve Giray, 2012, s.102).

İş ve yaşam tatmini ilişkisi 1980 'lerden itibaren yap1lan araştırmalarda (Rice, Near ve Hunt, 1980; Judge ve Watanabe, 1993; Dolan ve Gosselin, 2000; Georgellis ve Lange, 2007; Parlow, 2010; Wolfram ve Gratton, 2014) öncelikle taşma, daha sonra dengeleme ve bölünme olmak üzere üç teorik model çerçevesinde açıklanmaktadır

Taşma modeli, iş ve iş dıșı yaşam arasında pozitif yönde bir ilişkinin varlı̆̆ını ifade etmektedir Buna göre, kişinin işinden duyduğu tatmin, yaşam tatminini veya yaşamından duyduğu tatmin iş tatminini pozitif etkilemektedir. Dengeleme modeli, iş ve iş dişı yaşam arasında ters yönlü bir ilişkinin var olduğunu belirtmektedir. Başka bir deyişle bu yaklaşıma göre işinden memnun olmayan çalışanlar, iş dışı hayatlarında ödüller ve farklı deneyimler yoluyla daha fazla tatmin olmaya çalışmaktadırlar. Bu durumun tersi de mümkündür. Bölünme modelinde ise, iş ve iş dışı yaşam alanlarının birbirinden tamamen ayrı olduğu ve birbirini etkilemediğini ileri sürmektedir.

İş ve yaşam tatmininin hangisinin diğerini etkilediği veya belirlediği konusunda ise net bir şey söylemek zordur. Bu konuda diğer bir bakış açısı da iki değişken arasındaki ilişkinin nedensellikten ziyade, ilişkisel olup çift yönlü olduğudur (Kantak, Futrell ve Sager, 1992, s.2; Dolan ve Gosselin, 2000, s.5; Mishra v.d., 2014, s.7). İş tatmini ve yaşam tatmininin karş1lkklı ilişki içerisinde olduğu kabul edilirse, müşteri tatminine giden yolda iș ortamına ilișkin sorunların iş tatminini olduğu gibi yaşam tatmini de etkileyeceği sonucuna varılabilir.

\section{Araştırmanın Yöntemi}

Tanımlayıcı türde tasarlanan araştırmada veriler, geliştirilen bir anket ile toplanmıştır. Anketin geliştirilmesi aşamasında, restoran sektöründe uzmanlaşmış üç kişiyle görüşme yapılmış ve çalışanların kendilerine ne tür sorunları bildirdikleri öğrenilmiştir. Ayrıca Mersin il merkezinde dört fast-food işletmesi seçilmiş ve her birinden üç çalışan ile de derinlemesine görüşme gerçekleştirilmiştir.
Görüşmelerden ve alan yazından yararlanılarak hazırlanan anket, 2011 yılı Nisan ayında Mersin'deki 3 fast-food işletmesinden her birinden üç çalışana uygulanarak ön teste tabi tutulmuştur. Böylece veri toplamada kullanılacak olan ölçeğin içerik geçerliliği sağlanmaya çalışılmıştır. Sınırlı sayıda çalışan ile görüşme ve ön test yapılmasının nedeni, fast-food işletmelerinde genelde yoğun şekilde çalışılmasıdır (YYlmaz, 2010, s.6). İçerik geçerliliği sağlanmaya çalış1lırken, çalışanlarla öncelikle işletme dışında randevu alınmasına çalışılmış, ancak iş yoğunluğu nedeniyle ve işyeri sahiplerinin olumsuz yaklaşımları sonucu sınırlı düzeyde çalışanla görüşme ve ön test gerçekleştirilebilmiştir. Ön testle, anlaşılmayan, açık olmayan sorularda düzeltmelere gidilmesi planlanmış, fakat herhangi bir soru ya da ifadenin anlaşılmasında sorun olmadığı tespit edilmiştir.

Fast-food çalışanlarının sorunlarının belirlenmeye çalışıldığı ölçekte 22 madde bulunmaktadır. Bu maddelerin yazımında yapılan görüşmelerin yanı sıra alan yazından (Taner, 1993; Brown ve Peterson, 1994; Law, Pearce ve Woods, 1995; Uslu ve Demirel, 2002; Uçkun, Pelit ve Emir, 2004; Sy, Tram ve O'Hara, 2006; Aziz, Goldman ve Olsen, 2007; Pienaar ve Willemse, 2008; Soysal, 2009) da yararlanılmıştır. Bu ölçekte yer alan maddelerin yanit kategorileri 5'li derecelemeye tabi tutulmuştur (1: hiçbir zaman, 2: nadiren, 3: ara sıra, 4: genellikle, 5: her zaman). Araştırmada, çal1şanlara 3 maddeden oluşan iş tatmini (Sy, Tram ve O'Hara, 2006, s.466) ve 4 maddeden oluşan yaşam tatmini ölçeği (Diener vd., 1985, s.72) de uygulanmıştır. Bu ölçeklerin yanıt kategorileri de 5'li derecelemeye (1: Kesinlikle katılmıyorum, 2: Katılmıyorum, 3: Kararsızım, 4: Katılıyorum, 5: Kesinlikle Katılıyorum) tabi tutulmuştur.

Araştırmanın evrenini, Mersin şehir merkezinde faaliyet gösteren fast-food işletmelerinin çalışanları oluşturmaktadır. Evrende yer alan işletme sayısını belirlemek amacıyla Mersin Büyükşsehir Belediyesi, Akdeniz Belediyesi, Yenişehir Belediyesi, Mezitli Belediyesi ve Esnaf ve Sanatkârlar Odasından bilgi talebinde bulunulmuştur. Ancak, sağlıklı bir bilgiye erişilememiştir. Evren büyüklügüüün kestirilememesi nedeniyle, örneklem büyüklügünün hesabı da yapılamamıştır. Geliştirilen anket, Mersin il merkezinde faaliyet gösteren, araştırmanın yapılmasına izin veren fast-food işletmelerindeki çalışanlara bırak-topla tekniği kullanılarak, kolayda örneklemeye göre uygulanmıştır. Bırak-topla tekniğine başvurmanın nedeni, 
işyeri sahiplerinin araştırmaya çok sıcak bakmamaları ve çalışanların yoğun iş temposunu neden göstermeleridir. Anketin uygulaması 15 Mayıs-15 Ağustos 2011 tarihleri arasında gerçekleştirilmiştir. Zaman diliminin özel bir sebebi olmamakla birlikte, üç aylık bir süreyi kapsamasının nedeni, işyeri sahiplerinin sürece yeterli desteği vermemeleri sonucu anket uygulama sürecinin uzamasıdır.

İşletmeler, iş yapabilme potansiyellerinin büyüklügüne göre şehrin üç farklı ilçesinden seçilmiştir. Görüşmeler sonunda; 9'u Forum Alışveriş Merkezi, 6’sı Pozcu semti, 5’i Mezitli ilçesi ve 4’ü Akdeniz ilçesinde (şehir merkezi) olmak üzere toplam 24 fast-food işletmesinden anket uygulamasına izin alınabilmiştir. $\mathrm{Bu}$ işletmelere toplamda 243 adet anket bırakılmış, 15 Ağustos itibariyle doldurulan anket sayısı 174 olmuştur. Anket uygulama sürecindeki zorlukları dikkate alarak, örnek büyüklüğünün faktör analizi için yeterli olduğu kanaatine varılmıştır. Bu konuda, faktör analizi için madde başına 5 veya 10 katına kadar örnek büyüklügü yeterli görülebilmektedir (Çokluk, Şekercioğlu ve Büyüköztürk, 2010, s.206; Alpar, 2013, s.290). Ölçekte 22 madde bulunduğundan örneklem: madde sayısı oranı 8 'dir.

Anketler yoluyla elde edilen veriler bilgisayar ortam1na aktarılarak, tasnif ve analiz edilmiştir. Analizlerde frekans, oran ve ortalamaların yanı sıra, faktör analizi, korelasyon analizi, t-testi, ANOVA ve regresyon analizinden yararlanılmıştır.

Fast-food çalışanlarının sorunlarına ilişkin ölçeğin bir bütün olarak güvenirlik katsayısı Alfa 0,941'dir. İkiye bölerek yapılan analizde ilk yarının değeri 0,906 ve ikinci yarının değeri 0,871 'dir. Ölçeğe ait maddetoplam korelasyonlarının 0,240 ile 0,792 arasında değiştiği görülmektedir. İş tatmini ölçeğinin iç tutarlılık katsayısı 0,679 olup; yaşam tatmini ölçeğinde bu katsayı 0,868'dir. Tüm bunlar, iki ölçeğin de güvenilir olduğunu göstermektedir (Kalaycı, 2006, s.405).

\section{Bulgular ve Değerlendirme}

Araştırmaya katılan fast food çalışanlarının demografik özelliklerine bakıldığında 80'inin (\%46) kadın, 94’ünün (\%54) erkek olduğu, yaş aralı̆̆ının 18 ile 55 arasında değişmekte olup; \%75'inin yaşının 30 yaş ve altında olduğu, \%60'ının bekâr, \%40'ının ise evli olduğu görülmektedir.
Fast-food çalışanlarının sorunlarının kaç grupta incelenebileceğini tespit etmek için 22 maddeli ölçeğe faktör analizi uygulanmıştır. Faktör analizi uygulanırken faktör sayısının tespitinde öz değeri l'den büyük olanlar tercih edilmiştir. Ayrıca herhangi bir maddenin bir faktöre boyutlanabilmesi için ilgili faktör ile en az 0,500 düzeyinde korelasyona sahip olmasına (Hair vd., 2010, s.117), bir faktörün en az 3 maddeden oluşmasına (Şencan, 2005, s.362), binişik madde durumunda iki faktör arasındaki korelasyon farkının en az 0,100 düzeyinde olmasına (Tavşancil, 2002, s.50; Çokluk, Şekercioğlu ve Büyüköztürk 2012, s.233) ve Varimax dönüşümü uygulanmasına karar verilmiştir. Faktör analizi sonucu Tablo 1'de görülmektedir.

Yapılan ilk faktör analizinde 6. (Çalışanlar arası ayrım/ kayırmacılık ile ilgili sorunlar), 17. (İşlerin çalışanlar arasında dengeli veya adil bir şekilde dağılımı ile ilgili sorunlar) ve 21. (Çalışanlar arası sosyal etkileşim ile ilgili sorunlar) maddelerin binişik ve yük farkının 0,100'den düşük olduğu tespit edilmiştir. Bu nedenle bu maddeler ölçekten çıkarılarak, kalan 19 madde nihai faktör analizine alınmıştır. Yapılan analiz tüm varsayımları karşılamışve üçfaktör ortaya koymuştur.

Bu üç faktörün, toplam varyansın \%67,557'sini açıkladığ 1 görülmüsstür. Analizde KMO örneklem yeterliliği ölçüsü \%90,3 olarak hesaplanmış olup; Bartlett Küresellik testi 0,0001 düzeyinde $\left(X^{2}: 2393,542\right.$, sd: $171, \mathrm{p}<$,0001) anlamlıdır. Bu iki ölçüt, veri setinin faktör analizine uygun olduğunu ve analize devam edilebileceğini göstermektedir. Bartlett Küresellik testinin anlamlı olması, verilerin çok değişkenli normal dağılımdan geldiğine de bir işaret oluşturmaktadır (Çokluk, Şekercioğlu ve Büyüköztürk, 2010, s. 208). Bu test aynı zamanda, maddeler arasinda anlamlı korelasyonlar olduğunu göstermekte, dolayısyyla veri setinin faktör analizine uygunluğuna da bir kanıt oluşturmaktadır (Kalaycı, 2006, s.327).

Tablo l'e göre ilk faktör, toplam varyansın \%27'sini açıklamakta ve yedi maddeden oluşmaktadır. Faktörde çalışanların performans ölçümü, amirlerin çalışanlara dönük tutumları, performans değerleme, terfi işlemleri gibi maddeler bir araya gelmiştir. Bu maddeler aynı zamanda, majör maddelerdir. Bu faktöre "yönetsel sorunlar" adı verilmiştir.

İkinci faktör, ekip çalışması, motivasyon, işletmeye ve çalışanlara duyulan güven, çalışanlar arası ileti- 
Tablo 1. Fast-Food Çalışanlarının İ̧ Sorunlarına İlişkin Faktör Analizi Sonuçları

\begin{tabular}{|c|c|c|c|c|c|}
\hline & Yükü & Özdeğeri & A.Varyans & Ortalama & Alfa \\
\hline I.YÖNETSEL SORUNLAR (7 Madde) & & 5,134 & 27,021 & 1,6059 & .919 \\
\hline Çalışanların performanslarının ölçümü ile ilgili sorunlar &, 840 & & & & \\
\hline Amirlerin çalışanlara karşı tutumlarıyla ilgili sorunlar &, 809 & & & & \\
\hline Çalışanların performanslarının değerlendirilmesi ile ilgili sorunlar &, 805 & & & & \\
\hline Terfi/tayin imkânı ile ilgili sorunlar &, 725 & & & & \\
\hline İşyerinin fiziki düzenlemesiyle ilgili sorunlar & ,699 & & & & \\
\hline Yöneticiler ve çalışanlar arası sosyal etkileşim ile ilgili sorunlar & ,682 & & & & \\
\hline Amirlerin çalışanlara verdiği değer ile ilgili sorunlar & ,645 & & & & \\
\hline II.ÇALIŞANLAR ARASI SORUNLAR (6 Madde) & & 4,277 & 22,512 & 1,6992 & .913 \\
\hline Ekip çalışması ile ilgili sorunlar &, 813 & & & & \\
\hline Motivasyon ile ilgili sorunlar & ,790 & & & & \\
\hline İşletmeye duyulan güven ile ilgili sorunlar & ,779 & & & & \\
\hline Çalışanların birbirine güveni ile ilgili sorunlar & ,719 & & & & \\
\hline Çalışanlar arası iletişim ile ilgili sorunlar & ,704 & & & & \\
\hline Üstlenilen işlerin ağırlığıyla/zorluğuyla ilgili sorunlar & ,604 & & & & \\
\hline $\begin{array}{c}\text { III.ÇALIŞMA KOŞULLARI İLE } \\
\text { İLGILİ SORUNLAR (6 Madde) }\end{array}$ & & 3,425 & 18,025 & 3,0287 & .847 \\
\hline Çalışma saatlerinin uzunluğu ile ilgili sorunlar & ,858 & & & & \\
\hline Ücret ile ilgili sorunlar &, 774 & & & & \\
\hline Müşterilerin çalışanlara karşı tutumları ile ilgili sorunlar & ,699 & & & & \\
\hline Sürekli ayakta kalma zorunluluğu ile ilgili sorunlar & ,698 & & & & \\
\hline Sosyal faaliyetlere ayrılan zaman ile ilgili sorunlar & ,694 & & & & \\
\hline Mesai saatlerinde verilen dinlenme zamanı ile ilgili sorunlar &, 565 & & & & \\
\hline \multicolumn{6}{|c|}{$\begin{array}{l}\text { Faktör çıarma metodu: Temel bileşenler analizi; Döndürme metodu: Varimax } \\
\text { KMO Örneklem Yeterliliği: \%90,3; Bartlett's Küresellik Testi için } X^{2}: 2393,542 ; \text { sd: } 171 ; \mathrm{p}<0.0001 \text {; } \\
\text { Açıklanan toplam varyans: \%67,557; Ölçeğin tamamı için güvenirlik katsayıs1: .926 } \\
\text { Yanıt kategorileri: 1: hiçbir zaman, 2: nadiren, 3: ara sıra, 4: genellikle, 5: her zaman }\end{array}$} \\
\hline
\end{tabular}

şim gibi maddelerden oluşmaktadır. Altı maddeden oluşan bu faktöre "çalışanlar arası sorunlar" adı verilmiştir. Neredeyse tüm maddeler majör madde durumundadır. Bu faktör, toplam varyansın \%22,5'ini açıklamaktadır.

Üçüncü ve son faktör altı maddeden oluşmakta ve toplam varyansın \%18'ini açılamaktadır. Faktörde çalışma saatlerinin uzunluğu, ücretler, müşteri davranışları, sürekli ayakta kalma zorunluluğu gibi majör maddeler bir araya gelmiş olup; bundan dolayı da faktöre "çalışma koşulları ile ilgili sorunlar" adı verilmiştir.

Böylece fast-food çalışanlarının sorunlarının üç başlıkta incelenebileceği tespit edilmektedir. Bu sorunlardan göreceli olarak en sık yaşananı "çalışma koşulları ile ilgili sorunlar"dır (ortalama: 3,0287). İkinci sıradaki "çalışanlar arası sorunlar" (ortalama: 1,6992) ve üçüncü sıradaki "yönetsel sorunlar"in (ortalama: 1,6059) çalışanların göreceli olarak daha düşük sıklıklarla yaşadıkları sorunlar olduğu görülmektedir.

Katılımcıların iş tatmini ortalamaları 3,83, yaşam tatmini ortalamaları ise 2,96 olarak bulunmuştur. $\mathrm{Bu}$ durum, çalışanların iş tatmin düzeyleriyle ilgili soru- larda olumlu yönde fikir belirttiklerini göstermektedir. Yaşam tatmini ortalamaları daha düşük olmakla beraber yine de yaşam tatminine ilişkin sorulara ortalama düzeyde bir katılımı göstermektedir.

Araştırmada belirlenen faktörlerin ve iş ve yaşam tatmini ortalamalarının, çalışanların kimi demografik özelliklerine göre farklılık gösterip göstermediğini anlamak için t-testi yapılmıştır. T-testi sonuçları, Tablo 2'de özetlenmiştir.

Tablo 2'ye göre, yönetsel ve çalışanlar arası sorunlar bağlamında, kadın ve erkek çalışanlar sorunları aynı derecede algılamakta ve yaşamaktadır. Ancak çalışma koşulları konusunda kadınlar erkeklere kıyasla daha muzdariptir. Başka bir ifadeyle, kadınlar, çalışma koşullarıyla ilgili sorunları daha sık yaşamaktadırlar.

Diğer taraftan, yaşa göre sağlıklı bir değerlendirme yapabilmek amacıyla araştırmaya katılanlar $18-29$ ve 3055 yaş arası olmak üzere iki gruba bölünmüştür. Yapılan karşılaştırmada, yine yönetsel ve çalışanlar arası sorunlarda farklılık tespit edilemezken, çalışma koşulları bakımından farklılık ortaya çıkmıştır. Göreceli olarak gençler, orta yaş grubuna kıyasla çalışma koşulları ile ilgili sorunlarla daha sık karşılaşmaktadırlar. 


\begin{tabular}{|c|c|c|c|c|c|c|}
\hline & & $\mathrm{N}$ & Ortalama & Std. Sapma & t-değeri & p-değeri \\
\hline \multirow[t]{2}{*}{ Çalışma koşulları } & Kadın & 80 & 3,2125 & ,99152 & \multirow[t]{2}{*}{2,116} & \multirow[t]{2}{*}{.036} \\
\hline & Erkek & 94 & 2,8723 & 1,10889 & & \\
\hline \multirow[t]{2}{*}{ Çalışma koşulları } & 18-29 yaş arası & 120 & 3,1708 & 1,03272 & \multirow[t]{2}{*}{2,664} & \multirow[t]{2}{*}{.008} \\
\hline & $30-55$ yaş aras 1 & 54 & 2,7130 & 1,08420 & & \\
\hline \multirow[t]{2}{*}{ Çalışma koşulları } & Evli & 69 & 2,8213 & 1,09564 & \multirow[t]{2}{*}{$-2,099$} & \multirow[t]{2}{*}{.037 } \\
\hline & Bekar & 105 & 3,1651 & 1,03065 & & \\
\hline \multirow[t]{2}{*}{ Yönetsel sorunlar } & Bahşiş Evet & 105 & 1,4925 & ,86806 & \multirow[t]{2}{*}{$-2,152$} & \multirow[t]{2}{*}{.033} \\
\hline & Bahşiş Hayır & 69 & 1,7785 & ,84072 & & \\
\hline \multirow[t]{2}{*}{ Çalışanlar arası sorunlar } & Bahşiş Evet & 105 & 1,5810 & ,83593 & \multirow[t]{2}{*}{$-2,261$} & \multirow[t]{2}{*}{.025} \\
\hline & Bahşiş Hayır & 69 & 1,8792 & ,87395 & & \\
\hline \multirow[t]{2}{*}{ İş̧ tatmini } & Bahşiş Evet & 105 & 4,0127 & ,92210 & \multirow[t]{2}{*}{3,163} & \multirow[t]{2}{*}{.002} \\
\hline & Bahşiş Hayır & 69 & 3,5652 & ,89899 & & \\
\hline
\end{tabular}

Yanıt kategorileri: 1: hiçbir zaman, 2: nadiren, 3: ara sıra, 4: genellikle, 5: her zaman

Evli-bekâr olup olmama bakımından yapılan kıyaslamada, yine yönetsel ve çalışanlar arası sorunlarda farklılık bulunamazken, çalışma koşullarına ilişkin sorunlarda bekârların daha yüksek ortalamaya sahip oldukları görülmektedir.

Bahşiş alma durumuna göre ise önceki karşılaştırmaların tersine bir durum ortaya çıkmaktadır. Çalışma koşulları ortalamaları arasında bahşiş alma durumuna göre herhangi bir farklılık bulunamazken, yönetsel ve çalışanlar arası sorunların ortalamaları arasında bahşiş alma durumuna göre farklılık ortaya çıkmıştır. Buna göre, bahşiş almayanlar, bahşiş alanlara kıyasla bu sorunları daha sık yaşadıkları yönünde fikir belirtmişlerdir.

İş ve yaşam tatminleri açısından bakıldığında ortalamalar arası cinsiyet ve medeni durum açısından anlamlı bir farklılık bulunmazken, evli olanların iş ve yaşam tatminlerinin daha yüksek olduğu dikkat çekmektedir. Bahşiş alma durumuna göre ise iş ve yaşam tatmini ortalamaları farklılık göstermektedir. Bahşiş alanların iş ve yaşam tatmini ortalamalarının daha yüksek olduğu görülmekle beraber, bahşişin sadece iş tatmini ortalamaları üzerindeki farkı istatistiksel açıdan anlamlı bulunmuştur.

Fast-food çalışanlarının sorunlarının iş ve yaşam tatminleriyle ilişkisini ortaya koymak amacıyla korelasyon analizi yapılmıştır. Tablo 3’de görüldüğü üzere, tüm korelasyonlar ,01 düzeyinde anlamlıdır ve yönetsel sorunlar ile çalışanlar arası sorunlar boyutları arasında ( $\mathrm{r}: 0,743)$ pozitif-kuvvetli bir iliş̧i söz konusudur. Bu durum, yönetsel sorunlar arttıkça, çalışanlar arası sorunların da arttığı şeklinde yorumlanabilir. Diğer taraftan, yönetsel sorunlar ile çalışma koşulları (r:0,392) arasında zayıf ve çalışanlar arası sorunlar ile çalışma koşullar arasında (r: 0,484) orta düzeyli pozitif bir ilişki bulgulanmaktadır.

Dikkat çeken başka bir husus, iş tatmini ile yaşam tatmini arasında orta düzeyli (r: 0,588) pozitif yönlü bir ilişkinin varlığının yanı sıra, fast-food çalışanlarının üç boyutta özetlenen sorunları ile iş ve yaşam tatminleri arasında düşük düzeyde negatif ilişkilerin varlığıdır.

Tablo 3. Fast-Food Çalışanlarının İ̧s Sorunları, İş ve Yaşam Tatminleri Arasındaki Ilişki

\begin{tabular}{|l|r|r|r|c|c|c|}
\hline & Ortalama & Std. Sapma & $\begin{array}{c}\text { Çalışanlar } \\
\text { arası sorunlar }\end{array}$ & $\begin{array}{c}\text { Çalı̧ma } \\
\text { koşulları ile } \\
\text { ilgili sorunlar }\end{array}$ & İş tatmini & $\begin{array}{c}\text { Yaşam } \\
\text { tatmini }\end{array}$ \\
\hline Yönetsel sorunlar & 1,6059 &, 86631 &, 743 &, 392 &,- 233 &,- 362 \\
\hline Çalışanlar arası sorunlar & 1,6992 &, 86122 & - &, 484 &,- 366 &,- 375 \\
\hline $\begin{array}{l}\text { Çalışma koşulları ile } \\
\text { ilgili sorunlar }\end{array}$ & 3,0287 & 1,06717 & - & - &,- 221 &,- 426 \\
\hline İş tatmini & 3,8352 &, 93648 & - & - & - &, 588 \\
\hline Yaşam tatmini & 2,9626 &, 85344 & - & - & - & - \\
\hline
\end{tabular}


Fast food çalışanlarının sorunlarının iş ve yaşam tatminleri üzerindeki etkisini anlayabilmek için kademeli regresyon uygulanmıștır. Tablo 4 regresyon sonuçlarını göstermektedir. Tablo 4'e göre, fast-food çalışanlarının yaşam tatminini etkileyen işyeri sorunlarına ilişkin kurulan model anlamlıdır $\left(\mathrm{F}_{2: 171}: 25,008\right.$; $a<0,0001)$. Oto-korelasyon ve çoklu bağlantı probleminin olmadığı modelde; çalışma koşulları ve yönetsel sorunlar, fast-food çalışanlarının yaşam tatminlerini olumsuz yönde etkilemektedir. Çalışma koşulla- rına ilişkin sorunlardaki bir birimlik artış, yaşam tatmininde 0,336 birimlik azalışa yol açarken, yönetsel sorunlarda bu azalış 0,230 düzeyindedir.

Model iş tatmini açısından kurulduğunda, iş tatminini sadece çalışanlar arası sorunların olumsuz yönde etkilediği belirlenmiştir. Geçerli olan modele $\left(\mathrm{F}_{1 ; 172}: 26,670 ; \alpha<0,0001\right)$ göre, çalışanlar arası sorunlardaki bir birimlik artış, iş tatmininde 0,366 birimlik azalışa yol açmaktadır.

Tablo 4. Fast-Food Çalışanlarının Yaşam ve İs Tatminlerini Etkileyen İ̧ Sorunlarına İlişkin Regresyon Analizi Sonuçları

\begin{tabular}{|c|c|c|c|c|c|c|c|}
\hline & \multicolumn{2}{|c|}{$\begin{array}{l}\text { Standardize Edilmemiş } \\
\text { Katsayılar }\end{array}$} & \multirow{2}{*}{$\begin{array}{c}\text { Standardize } \\
\text { Katsayılar }\end{array}$} & \multirow[b]{2}{*}{$\mathrm{T}$} & \multirow{2}{*}{$\begin{array}{l}\text { Anlam } \\
\text { Düzeyi }\end{array}$} & \multicolumn{2}{|c|}{$\begin{array}{l}\text { Çoklu Bağlantı } \\
\text { İstatistikleri }\end{array}$} \\
\hline & $\mathrm{B}$ & Std. Hata & & & & Tolerans & VIF \\
\hline (Sabit) & 4,140 & ,179 & & 23,159 &, 000 & & \\
\hline Çalışma koşulları &,- 269 & ,058 &,- 336 & $-4,597$ &, 000 & ,846 & 1,181 \\
\hline Yönetsel sorunlar &,- 226 & ,072 &,- 230 & $-3,143$ & ,002 & ,846 & 1,181 \\
\hline \multicolumn{8}{|c|}{$\begin{array}{l}\text { Bağımlı değişken: Yaşam Tatmini; Model } \mathrm{F}_{2 ; 171}: 25,008 ; \alpha<0,0001 \text {;Durbin-Watson: } 1,888 \text {; } \\
\text { R: .476, } \mathrm{R}^{2}: \% 22,6 \text {; Düzeltmiş } \mathrm{R}^{2}: \% 21,7 ; \text { En büyük CI (koşul indeksi): 7,091 }\end{array}$} \\
\hline (Sabit) & 13,537 & ,441 & & 30,721 &, 000 & & \\
\hline $\begin{array}{l}\text { Çalışanlar arası } \\
\text { sorunlar }\end{array}$ & $-1,195$ & ,231 &,- 366 & $-5,164$ & ,000 & 1,000 & 1,000 \\
\hline \multicolumn{8}{|c|}{$\begin{array}{l}\text { Bağımlı değişken: İş Tatmini; Model } \mathrm{F}_{1: 172}: 26,670 ; \alpha<0,0001 ; \text { Durbin-Watson:2,046; } \\
\text { R: .366, } \mathrm{R}^{2}: \% 13,4 \text {; Düzeltmiş } \mathrm{R}^{2}: \% 12,9 ; \text { En büyük CI (koşul indeksi): 4,196 }\end{array}$} \\
\hline
\end{tabular}

\section{Sonuç ve Tartışma}

$\mathrm{Bu}$ araştırmada, Mersin şehir merkezinde faaliyet gösteren fast-food işletmelerindeki çalışanların sorunları tespit edilmeye çalışılmıştır. Araştırmaya katılan fast food çalışanlarının çoğunluğunun genç ve bekarlardan oluştuğu görülmektedir. Alanyazındaki fast-food işletmelerini uygulama alanı olarak almış araştırmaların geneline bakıldığında, ağırlıklı olarak genç ve bekâr çalışanlara sahip olmanın, fast-food işletmelerinin tipik özelliklerinden olduğu görülmektedir. Araştırmaya katılanların \%37'si asgari ücret dolayında ücret alırken, \%55'i 700-1000.-TL arasında ücret almaktadır. ABD istatistiklerine göre, 2010 y1lında bu sektörde çalışanlar yıllık medyan değeri olarak 17.950 ABD Doları kazanç elde etmekte ve meslek sinıfları bakımından son sırada yer almaktadırlar (Lockard ve Wolf, 2012, s.101). Ayrica Almanya ve İngiltere gibi kimi ülkelerde fast-food çalışanlarının bir kısmının yaşça daha büyük kişilerden oluşabileceği ifade edilmekle birlikte, dünya genelinde bu tarz işletmelerde çalışanların genellikle daha genç oldukları belirtilmektedir (Gould, 2009, s.376). Öte yandan Giezen (1994, s.24) de fast-food çalışanlarının gençlerden ve bekârlardan oluştuğunu belirtmektedir.
Araştırma sonuçlarına göre, fast-food çalışanlarının yaşadıkları sorunların yönetsel, çalışanlar arası ve çalışma şartlarıyla ilgili sorunlar olarak üç başlık altında toplandığ 1 tespit edilmiştir. Bu açıdan çalışma sonuçları alanyazındaki diğer çalışmalarla büyük ölçüde benzerlik göstermektedir. Law, Pearce ve Woods (1995, s.279) genel olarak hizmet sektöründe çalışanların yaşadıkları genel sorunların "iş ortamı koşulları, örgütsel yapı, görev belirsizliği, görev çatışması, zayıf yönetim, zayıf iletişim, sorunlu müşteriler ve aşırı iş yükü" olduğunu belirtmektedir. Bunlara "çalışanlar arası ekip çalışmasının zayıf olması, iletişim eksikliği, bilgi yetersizliği, güven ortamının olmayışı, çalışanların motivasyonun sağlanamaması, çalışanların hak ettikleri ücreti alamamaları, çalışanlar ile üst yönetimin amaç ve hedeflerindeki farklılıklar ve çalışanlar arasındaki adam kayırmacılık" gibi sorunlar da eklenmektedir (Kuşluvan ve Kuşluvan, 2005, s.186).

Ancak sorunların ortalamalarına bakıldığında, yaşanan sorunlardan yönetsel ve çalışanlar arası sorunların nadiren (ortalama $=1,60 ; 1,69$ ), çalışma koşullarına ilişkin sorunların ise ara sıra yaşandığı (ortalama= 
3,02) ortaya çıkmaktadır. Ayrıca araştırmaya katılanların iş ve yaşam tatmini ortalamalarının da oldukça yüksek olduğu görülmektedir. Bu sonuç kendi içinde tutarlı ve mantıklı bir sonuçtur. Buna göre, sektör çalışanlarının yönetsel açıdan ve çalışanlar arası ilişkiler bakımından fazla sorun yaşamadığını göstermektedir. Sektörün imtiyaz anlaşmalarının yaygın kullanıldığı bir sektör olması ve yapısal özellikleri dolayısıyla işlerin belirli ve standart olması, sağlanan eğitim imkânlarının bu konuda etkili olduğu düşünülmektedir. Ayrıca çalışma koşullarına ilişkin sorunların, (ücretin bile) sektördeki işlerin giriş seviyesi işler olarak görülmesi ve de çalışanların ağırlıklı olarak, bekâr ve gençlerden oluşması dolayısıyla çok fazla sorun yaratmadığı ortaya çıkmıştır. Bu açıdan çalışmanın sonuçları ilgi çekicidir.

Belirlenen sorunlara genel olarak bakıldığında, "çalışma yaşamına ilişkin sorunları” kadınların erkeklere oranla daha sık yaşadığı tespit edilmiştir. Bu durum toplumun kadına yüklediği rollerle ilgili olduğu şeklinde yorumlanabilir. Öyle ki Japonya'da çalışan kadınlar 30-34 yaşları arasında erken emekliliğe ayrılmaktadır. Çünkü ev işleri ve çocuk bakımı kadının birincil görevleri arasında görülmektedir (Takahaski, 1994, s.50). Yazıcıoğlu ve Sökmen (2007, s.84) tarafından yapılan benzer bir çalışmada da kadın çalışanların "ücret, sürekli meşgul olma (işin yoğun olması), mesai saatlerinin uzun olması" gibi çalışma şartlarına ilişkin boyutlara karşı daha olumsuz bir tavır sergilediği bulgulanmıştır. Ayrıca Türkiyede çalışan 38 kadınla ayrıntılı görüşmeler yapılarak yürütülen bir araştırmada, bu kadınların 27'sinin maddi zorunluluk olmasa çalışmaktan vazgeçebileceklerini, evdeki yüklerinin işyerinde sorumluluk alma ve yükselme konusunda isteksiz olmalarına neden olduğunu belirtmiştir. $\mathrm{Bu}$ durumun yanında Türkiye'de kadınların çalışmalarını engelleyen eş, baba, kardeş gibi aile üyelerinin baskısının da kadının işyerinde yaşadığ çalışma şartlarına ilişkin sorunların sebepleri arasında olduğu söylenebilir (Kuzgun ve Sevim, 2004, s.17).

Yaşanan sorunlar yaşa göre değerlendirildiğinde, çalışma şartlarına ilişkin sorunlarda 18-29 yaş arasındakilerin 30-55 yaş arasındakilere kıyasla, bu sorunları daha sık yaşadıkları tespit edilmiştir. Bunun sebebi yaş ilerledikçe kişilerin olgunlaşması ve bunun neticesinde de pek çok durumun sorun olarak alg1lanmamasıyla açıklanabilir. Yaşça daha büyük olanların gençlere göre beklentilerinde daha gerçekçi olma- ları ve işsizlik nedeniyle de iş değişikliği konusunda gençler kadar cesaretli davranamamaları şeklinde de yorumlanabilir.

Met ve Sarığlan (2010, s.212) tarafindan otel işletmelerindeki yiyecek-içecek bölümlerinde çalışanlar üzerinde yapılan benzer bir araştırmada, bu araştırmanın sonucuna paralel olarak gençlerin işle ilgili sorunları daha çok yaşadıkları ifade edilmiştir. Toker (2007, s.101) tarafından otel işletmeleri çalışanları üzerinde yapılan benzer bir araştırmada da, yaşlı çalışanların genç çalışanlara kıyasla işlerinden daha çok memnun oldukları bulunmuştur. Michigan Üniversitesi Sosyal Araştırmalar Enstitüsü tarafından beş ayrı ülkede yürütülen çalışmalar sonucunda da, daha yaşlı çalışanların gençlere göre işlerinden daha fazla tatmin olduğu sonucuna varılmıştır (Davis, aktaran Toker, 2007, s.103). Araştırmanın sonuçları bu sonuçlarla örtüşmektedir.

Bahşiş alma durumuna göre yapılan analizlerde ise, yönetsel ve çalışanlar arası sorunların ortalamaları arasında bahşiş alma durumuna göre farklıllk ortaya çıkmıştır. Buna göre, bahşiş almayanlar, bahşiş alanlara kıyasla bu sorunları daha sık yaşadıkları yönünde fikir belirtmişlerdir. Ayrıca bahşiş alanların iş tatmini daha yüksek çımıştır. Bu durum, az da olsa sağlanan bu ekonomik katkının çalışanlar açısından önemli addedildiğinin bir göstergesi olarak yorumlanabilir. Lynn (2002, s.443) yiyecek-içecek işletmelerinde yapmış olduğu araştırmada, bahşiş miktarı ile personel devir hızı oranı arasında ters yönlü bir ilişki olduğunu tespit etmiştir. Yani, alınan bahşiş miktarı arttıkça personel devir hızı azalmaktadır. İnce (2008, s.67) de, çalışanların düşük ücret almalarından ötürü bahşişlerin onlar için önemli bir ekonomik katkı olduğunu ve çalışanların işe yönelik tutumlarında etkili olduğunu belirtmektedir.

Çalışmanın bir diğer ilgi çekici sonucunu ise belirlenen faktörlerin fast-food çalışanlarının iş ve yaşam tatminlerine olan etkisi oluşturmaktadır. İş tatmini üzerinde çalışanlar arası sorunlar olumsuz yönde etkili olmaktayken, yaşam tatmini üzerinde çalışma koşulları ve yönetsel sorunların yine olumsuz yönde etkisinin olduğu belirlenmiştir. Çalışanlar arası sorunların ekip çalışması, işletmeye ve çalışanlara duyulan güven, çalışanlar arası iletişim ve işlerin ağırlığıyla/ zorluğuyla ilgili sorunlar olduğu düşünüldügüüde, çalışanı iş tatmini açısından motive eden unsurların 
parasal olmayan unsurlardan oluştuğu anlaşılmaktadır. Bunlar işletme kültürü ile yakından ilgili konulardır. Dolayısıyla fast-food işletmelerinin yöneticilerine, örgütsel kültürü ve ortamı iyileştirmeleri tavsiye edilebilir.

Diğer taraftan, fast-food çalışanlarının yaşam tatminleri boyutuyla tartışma derinleştirildiğinde; yaşam tatminlerinin çalışma koşulları ve yönetsel sorunlarından olumsuz yönde etkilendiği belirlenmektedir. Yönetsel sorunlara bağlı olarak çalışma koşullarında meydana gelebilecek sorunlar, çalışanların işyeri $\mathrm{d}_{1}$ şındaki yaşam tatminlerini olumsuz etkilemekte, bu durum, işe ve işyerine karşı motivasyon sorunlarını da beraberinde getirebilmektedir.

Sonuç şaşırtıcı olmakla beraber mantıklıdır. Çalışma koşulları ve yönetsel sorunların yaşam tatmini üzerinde doğrudan etkisi varken, çalışanlar arası ilişkiler iş tatminini doğrudan etkilemektedir. Burada çalışma koşulları ve yönetsel sorunların taşma etkisiyle iş dışı yaşamı da etkilediği, ancak çalışanlar arası ilişkilerin sadece iş alanıyla sınırlı olması dolayısıyla iş tatmin düzeyi üzerinde etkili olduğu düşünülmektedir. Bunun yanı sıra, yapılan korelasyon analizi sonucunda iş ve yaşam tatmini arasında pozitif yönlü ilişki bulunmuş olması da, taşma modelini doğrular niteliktedir. Çalışma koşullarından kaynaklanan sorunlar ve yönetsel sorunların iş tatmini üzerinde doğrudan etkisinin olmaması, aracılık etkilerinin varlığını ve iş tatmini ile yaşam tatmini arasındaki ilişkinin yönünü de düşündürmektedir. Bu husus ilerde yapılacak araştırmalara bir öneri niteliğini de taşımaktadır.

Yapılan araştırma, sadece Mersin şehir merkezinde faaliyet gösteren, izin alınabilen sınırlı sayıdaki fastfood işletmelerinin çalışanları üzerinde gerçekleştirilmiştir. Bu nedenle, yapılan araştırma fast-food çalışanlarının sorunları ve bu sorunların onların iş ve yaşam tatminlerine etkileri konusunda genellenebilir sonuçlar sağlamada kısmen yetersiz kalsa da, konunun anlaşılmasına katkı sağladığı ve yöneticiler için bir karar destek zemini yaratabildiği düşünülmektedir. Bu çerçevede, fast-food çalışanlarına dönük daha büyük örneklem ile çalışllabileceği gibi, turizm işletmesi belgeli/belediye belgeli ve/veya alkollü/alkolsüz restoran/bar çalışanlarının sorunları üzerine yeni çalışmalar yapılabilir. Böylece benzerlikler ve farkl1lıklar ortaya konarak, yiyecek-içecek sektörü çalışanlarının sorunları daha derinlemesine öğrenilebilir.

\section{Kaynakça}

Akbay, C., Tiryaki, G. Y. ve Gül, A. (2007). Consumer characteristics influencing fast food consumption in Turkey. Food Control, 18, 904-913.

Allan, C., Bamber G. ve Timo, N. (2006). Fast food work: are McJobs satisfying? Employee Relations, 28(5), 402-420.

Alpar, R. (2013). Uygulamalı çok değişkenli istatistiksel yöntemler. Ankara: Detay.

Aziz, A., Goldman, H. M. ve Olsen, N. (2007). Facets of type A personality and pay increase among the employees of fast food restaurants. Hospitality $\mathrm{Ma}$ nagement, 26, 754-758.

Bitner, M. J., Booms, B. H. ve Mohr, L. A. (1994). Critical service encounters: The employees' viewpoint. Journal of Marketing, 58 (4), 95-106.

Brown, S. P. ve Peterson, R. A. (1994). The effect of effort on sales performance and job satisfaction. Journal of Marketing, 58, 70-80.

Bülbül, Ş. ve Giray, S. (2012). İş ve özel yaşam (iş dışı yaşam) memnuniyeti arasındaki ilişki yapısının doğrusal olmayan kanonik korelasyon analizi ile incelenmesi. Anadolu Üniversitesi Sosyal Bilimler Dergisi, 12 (4), 101-114.

Chi, C. ve Gursoy, D. (2009). Employee satisfaction, customer satisfaction, and financial performance: An empirical examination. International Journal of Hospitality Management, 28, 245-253.

Chiang, F. F. T., Birtch, T. A. ve Kwan, H. K. (2010). The moderating roles of job control and work-life balance practices on employee stress in the hotel and catering industry. International Journal of Hospitality Management, 29, 25-32.

Curtis, C. R., Upchurch, R. S. ve Severt, D. E. (2009). Employee motivation and organizational commitment: A comparison of tipped and nontipped restaurant employees. International Journal of Hospitality and Tourism Administration, 10 (3), 253-269.

Çoban, H. ve İrmiş, A. (2014). Duygusal emek ve iş tatmini ilişkisi: Hazır yemek sektörü çalışanlar1 üzerine bir araştırma. Bildiriler kitabı içinde (ss.871-879). 22. Ulusal Yönetim ve Organizasyon Kongresi Konya. 
Çokluk, Ö., Şekercioğlu, G. ve Büyüköztürk, Ș. (2012). Sosyal bilimler için çok değişkenli istatistik. Ankara: Pegem.

Dermody, M. B., Young, M. ve Taylor, S. L. (2004). Identifying job motivation factors of restaurant servers: Insight for the development of effective recruitment and retention strategies. International Journal of Hospitality and Tourism Administration, 5 (3), 1-14.

Diaz, P. E. ve Park J. (1992). The impact of isolation on hospitality employees' job satisfaction and job performance. Journal of Hospitality and Tourism Research, 15 (3), 41-49.

Diener, E., Emmons, R. A., Larsen, R. J. ve Griffin, S. (1985). The satisfaction with life scale. Journal of Personality Assessment, 49 (1), 71-75.

Dienhart, J. R. ve Gregoire, M. B. (1993). Job satisfaction, job involvement, job security, and customer focus of quick-service restaurant employees. Journal of Hospitality and Tourism Research, 16 (2), 29-43.

Dolan S. ve Gosselin E. (2000). Job satisfaction and life satisfaction: analysis of a reciprocal model with social demographic moderators. Working Paper University of Montreal, Erişim adresi: http://www. researchgate.net, Erişim tarihi: 15.12.2014.

Gavcar, E., Bulut, Z. A. ve Engin K. (2006). Konaklama işletmelerinde uygulanan performans değerleme sistemleri ve uygulama alanları. Yönetim ve Ekonomi, 13 (2), 31-45.

Georgellis, Y. and Lange, T. (2007). Traditional vs secular values and work-life balance across Europe. Erişim adresi: http://www.brunel.ac.uk/_data/assets /pdf_file/0007/84139/07-19.pdf, Erişim Tarihi: 15.12.2014.

Ghiselli, R., Lopa, J. ve Bai, B. (2001). Job satisfaction, life satisfaction, and turnover intent among foodservice managers. The Cornell Hotel and Restaurant Administration Quarterly, 42 (2), 28-37.

Giezen, R. W. V. (1994). Occupational wages in the fast-food restaurant industry. Monthly Labor Review, 24-30.

Gill, A., Flaschner, A. B., Shah, C. ve Bhutani, I. (2010). The relations of transformational leadership and empowerment with employee job satisfaction: A study among Indian restaurant employees. Business and Economics Journal, 1-10.
Gould, M.A. (2009). Fast food work: An empirical perspective of ideal employees. Industrial Relations, 64 (3), 376-398.

Guzman, M., Rodriguez, B. ve Manautou, P. (2004). The link between customer satisfaction and employee satisfaction in restaurant industry. http://www. tam.itesm.mx/documentos /ANEXO \%20004\%20 JUAN \%20DI.pdf, (erişim tarihi: 10.04.2013).

Hair, J. F., Black, W. C., Babin, B. J. ve Anderson, R. E. (2010). Multivariate data analysis a global perspective. New Jersey: Pearson.

Hançer, M. (2001). An analiysis of psychological empowerment and job satisfaction for restaurant employees. Ohio State Üniversitesi, Yayımlanmamış Doktora Tezi.

Hançer, M. ve George, R. T. (2003). Job satisfaction of restaurant employees: An empirical investigation using the Minnesota satisfaction Questionnaire. Journal of Hospitality and Tourism Research, 27 (1), 85-100.

Hartline, M.D. ve Farrell, O.C. (1996). The management of customer contact service employees: An empirical investigation. Journal of Marketing, 60, 52-70.

Hayes, C. T. ve Weathington, B. L. (2007). Optimism, stress, life satisfaction, and job burnout in restaurant managers. The Journal of Psychology, 141 (6), 565-579.

Heskett, J. L., Jones, T. O., Loveman, G. W., Sasser, W. E. ve Schlesinger, L. A. (1994). Putting the serviceprofit chain to work. Harvard Business Review 72 (2), 164-174.

İçigen, E. ve Uzut, İ. (2012). Yiyecek-içecek bölümü çalışanlarının mesleki tükenmişlikleri ve iş doyumları üzerine bir araştırma. Niğde Üniversitesi İIBF Dergisi, 5 (2), 107-118.

İnce, C. (2008). Toplam kalite yönetimi ve otel işletmelerinde işgören tatminine etkileri. Anatolia: Turizm Araştırmaları Dergisi, 19 (1), 57-70.

Judge, T. A. ve Watanabe, S. (1993). Another look at the job and life satisfaction. Journal of Applied Psychology, 78 (6), 939-948.

Kaçmaz, N. (2005). Tükenmişlik sendromu. İstanbul Üniversitesi Tip Fakültesi Dergisi, 68 (1), 29-32. 
Kalaycı, S. (2006). SPSS Uygulamalı çok değişkenli istatistik teknikleri. Ankara: Asil.

Kantak, D. M., Futrell, C. M. ve Sager, J. K. (1992). Job satisfaction and life satisfaction in a sales force. Journal of Personal Selling and Sales Management, 12 (1), 1-7.

Koys, D. J. (2001). The effects of employee satisfaction, organizational citizenship behavior, and turnover on organizational effectiveness: A unit-level, longitudinal study. Personnel Psychology, 54, 101-114.

Kozak, N. (2006). Turizm pazarlaması. Ankara: Detay.

Kuşluvan, Z. ve Kuşluvan, S. (2005). Otel işletmelerinde iş ve işletme ile ilgili faktörlerin işgören tatmini üzerindeki görece etkisi: Nevşehir örneği. Anatolia: Turizm Araştırmaları Dergisi, 16 (2), 183-203.

Kuzgun, Y. ve Sevim S. A. (2004). Kadınların çalışmasına karşı tutum ve dini yönelim arasındaki ilişsi. Ankara Üniversitesi Eğitim Bilimleri Fakültesi Dergisi, 37 (1), 14-27.

Lacey, T.A. ve Wright, B. (2009). Occupational employment projections to 2018. Montly Labor Review, Kasım, 82-123.

Lam, T. ve Zhang, H.Q. (2003). Job satisfaction and organizational commitment in the Hong Kong fast food industry. International Journal of Contemporary Hospitality Mananement, 15(4), 214-220.

Law, J., Pearce, P. L. ve Woods, B. A. (1995). Stres and coping in tourism attraction employees. Tourism Management, 16 (4), 277-284.

Lockard, C.B. ve Wolf, M. (2012). Occupational employment projections to 2020. Montly Labor Review, Ocak, 84-108.

Lynn, M. (2002). Turnover's relationships with sales, tips, and service across restaurants in a chain. International Journal of Hospitality Management, 21, 443-447.

Lynn, M. (2003). Tip levels and service: An update, extension, and reconciliation. The Cornell Hotel and Restaurant Administration Quarterly, 44, 139-148.

Met, Ö. L. ve Sarıoğlan, M. (2010). Otel işletmeleri yiyecek-içecek ünitelerinde işgören devri üzerine görgül bir araştırma. Adiyaman Üniversitesi Sosyal Bilimler Enstitüsü Dergisi, 5, 200-213.
Mishra, V., Nielsen, I., Smyth R. ve Newman, A. (2014). The Job Satisfaction-Life Satisfaction Relationship Revisited: Using the Lewbel Estimation Technique to Estimate Causal Effects Using Cross-Sectional Data. Monash Economics Working Papers, Erişim adresi: http://www.buseco.monash.edu.au/eco/research/papers/2014/2614jobmishranielsensmythn ewman.pdf, Erişim tarihi:15.12.2014.

Naseem A., Sheikh, S. E. ve Malik, K. P. (2011). Impact of employee satisfaction on success of organization: Relation between customer experience and employee satisfaction. International Journal of Multidisciplinary Sciences and Engineering, 2 (5), 41-46.

Park, C. (2004). Efficient or enjoyable? Consumer values of eating-out and fast food restaurant consumption in Korea (Research note). Hospitality Management, 23, 87-94.

Parlow, A. (2010). The work life conflict: the relationship between job and life satisfaction Erişim adresi: https://pantherfile.uwm.edu/aparlow/www/papers/jsls.pdf, Erişim Tarihi: 15.12.2014.

Pelit, E. ve Türkmen, F. (2008). Otel işletmeleri işgörenlerinin tükenmişlik düzeyleri: Yerli ve yabancı zincir otel işletmeleri işgörenleri üzerinde bir araştırma. Gazi Üniversitesi İktisadi ve İdari Bilimler Fakültesi Dergisi, 10 (1), 117-139.

Pienaar, J. ve Willemse, S. A. (2008). Burnout, engagement, coping and general health of service employees in the hospitality industry. Tourism Management, 29, 1053-1063.

Pizam, A. ve Lewis R. (1979). Predicting career success and satisfaction: A study of hospitality graduates. Cornell Hotel and Restaurant Administration Quarterly, 20 (3), 12-16.

Ram, P., Bhargavi G. S. ve Prabhakar, G. V. (2011). Work environment, service climate, and customer satisfaction: Examining theoretical and empirical connections. International Journal of Business and Social Science, 2 (20), 121-132.

Rice, R. W, Near, J. P. ve Hunt, R. G. (1980). The job satisfaction/life satisfaction relationship: A review of empirical research. Basic and Applied Social Psychology, 1, 37-64. 
Saari, L. M. ve Judge, T. A. (2004). Employee attitudes and job satisfaction. Human Resource Management, 43 (4), 395-407.

Saldaml, A. (2008). Otel işletmelerinde bölüm yöneticilerinin iş ve yaşam tatmini belirlemeye yönelik bir alan araştırması. Marmara Üniversitesi İktisadi ve İdari Bilimler Fakültesi Dergisi, 25 (2), 693-719.

Schlesinger, L. ve Heskett, J. (1991). Breaking the cycle of failure in services. Sloan Management Review, $32,17-28$.

Sezgin, E. K. ve Ünlüönen, K. (2011). Mutfak personelinin hizmet içi eğitiminin örgütsel bağlllık ve iş tatminine etkisi üzerine bir uygulama. İşletme Araştırmaları Dergisi, 3 (2), 3-16.

Soysal, A. (2009). Farklı sektörlerde çalışan işgörenlerde örgütsel stres kaynakları: Kahramanmaraş ve Gaziantep’te bir araştırma. Süleyman Demirel Üniversitesi İktisadi ve İdari Bilimler Fakültesi Dergisi, 14 (2), 333-359.

Spinelli, M. A. ve Canavos, G. C. (2000). Investigating the relationship between employee satisfaction and guest satisfaction. Cornell Hotel and Restaurant Administration Quarterly, 41 (6), 29-35.

Sy, T., Tram, S. ve O'Hara, L. A. (2006). Relation of employee and manager emotional intelligence to job satisfaction and performance. Journal of Vocational Behaviour, 68, 461-473.

Şencan, H. (2005). Sosyal ve davranışsal ölçümlerde güvenilirlik ve geçerlilik. Ankara: Seçkin.

Takahaski, M. (1994). The issues of gender in comtemporary Japanese working life: A Japanese "viciouscircle". Feminist Issues, 14 (1), 37-56.

Taner, B. (1993). Beş yıldızlı otellerde çalışanların iş tatmininin değerlendirilmesi. Anatolia, 22-24.

Tavşancil, E. (2002). Tutumların ölçülmesi ve SPSS ile veri analizi. Ankara: Nobel.
Tayfun, A. ve Tokmak, C. (2007). Tüketicilerin Türk Usulü Fastfood İşletmelerini Tercih Etme Sebepleri Üzerine Bir Araştırma. Gazi Üniversitesi Sosyal Bilimler Dergisi, 6 (22), 169-183.

Toker, B. (2007). Demografik değişkenlerin iş tatminine etkileri: İzmir'deki beş ve dört yıldızlı otellere yönelik bir uygulama. Doğuş Üniversitesi Dergisi, 8 (1), 92-107.

Uçkun, G., Pelit, E. ve Emir, O. (2004). Otel işgörenlerinin iş doyumlarının önemi ve Akçakoca'da yerleşik otel işletmeleri işgörenleri üzerinde bir uygulama. Ticaret ve Turizm Eğitim Fakültesi Dergisi, 1, 39-59.

Uslu, Ş. ve Demirel, Y. (2002). Kobilerde çalışanların sorunları üzerine bir araştırma. Sosyal Bilimler Enstitüsü Dergisi, 12, 173-184.

Uyguç N., Duygulu E., Arbak Y. ve Çıraklar N. (1998). İş ve yaşam doyumu arasındaki ilişkinin üç temel varsayım altında incelenmesi. Dokuz Eylül Üniversitesi İ.I.B.F. Dergisi, 13 (11), 193-204.

Wiley, J. W. (1991). Customer satisfaction: A supportive work environment and its financial cost. Human Resource Planning, 14 (2), 117-128.

Wolfram, H.J. ve Gratton, L. (2014). Spillover between work and home, role importance and life satisfaction. British Journal of Management, 25 (1), 77-90.

Yazıcıoğlu, İ. ve Sökmen, A. (2007). Otel işletmelerinin yiyecek-içecek departmanlarında görev yapan işgörenlerin iş tatmin düzeylerinin değerlendirilmesi: Adana’da bir uygulama. Muğla Üniversitesi Sosyal Bilimler Enstitüsü Dergisi, 18, 73-95.

Yilmaz, H. Z. (2010). Fast food sektöründe çalışanlarm başarma güdüsünün organizasyonel bağlliğga etkisi. İstanbul Üniversitesi Sosyal Bilimler Enstitüsü İşletme Anabilim Dalı. Yayımlanmamış Yüksek Lisans Tezi.

Zeithaml, V. A., Parasuraman, A. ve Berry, L. L. (1985). Problems and strategies in services marketing. Journal of Marketing, 49, 33-46. 